\title{
ANÁLISE DO "NORMATIZAR" DA CRISE VENEZUELANA NO BRASIL E SUA RELAÇÃO COM A POLÍTICA DISCURSIVA DA OPERAÇÃO ACOLHIDA
}

Victória Figueiredo MACHADO ${ }^{1}$

RESUMO: A partir de uma análise político-midiática do recrudescimento do movimento migratório venezuelano em direção ao Brasil principalmente no ano de 2017, o artigo busca investigar a natureza bilateral, concomitante da governança humanitária brasileira relacionada ao cuidado e controle, benevolência e ameaça. Essa dinâmica é reforçada em 2018 com a criação da Operação Acolhida, que será exposta no artigo através da observação de imagens e vídeos oficiais e de um breve e incipiente estudo de campo. Pretende-se questionar como o imaginário de emergência que a mídia e os políticos estavam mobilizando, acaba (re)produzindo através de práticas discursivas, visuais, estéticas da Operação uma visão de alteridade, sobre quem são os brasileiros e quem são os venezuelanos. $\mathrm{O}$ artigo utiliza a abordagem pós-estruturalista, focando na construção discursiva de subjetividades e da identidade coletiva da "nação brasileira", bem como nas consequências políticas de determinados discursos e práticas no tocante à identidade, segurança e mobilidade, tomando como aporte metodológico a análise de discurso. Nesse sentido, investigar estratégias de representação performatizadas pelo Exército brasileiro que transformam o espetáculo ameaçador da "enxurrada, invasão de refugiados " em um palco compassivo de cuidado, benevolência torna-se central para esse artigo, em como expor a vulnerabilidade migratória vivenciada nesse processo.

PALAVRAS-CHAVE: migraçôes; identidades; forças armadas; fronteiras; operação Acolhida.

\footnotetext{
1 PUC-Rio. Rio de Janeiro - RJ - Brasil. Mestranda em Relações Internacionais. vicfigueiredo09@hotmail.com. https://orcid.org/0000-0002-8694-1164.
} 


\section{ANALYSIS OF THE "NORMATIZING" OF THE VENEZUELAN CRISIS IN BRAZIL AND ITS RELATIONSHIP TO DISCURSIVE POLICY OF "OPERAÇÃO ACOLHIDA"}

ABSTRACT: Based on a political-media analysis of the resurgence of the Venezuelan migratory movement towards Brazil, especially in 2017, the article aims to investigate the bilateral, concomitant nature of Brazilian humanitarian governance related to care and control, benevolence and threat. This dynamic is reinforced in 2018 with the creation of the "Operaçâo Acolhida", which will be exposed in the article through the observation of official images and videos and a brief and incipient field study. It is intended to question how the imaginary of emergency that the media and politicians were mobilizing ends up (re) producing, through discursive, visual, aesthetic practices of the Operation, a vision of otherness, about who are Brazilians and who are Venezuelans. The article uses the poststructuralist approach, focusing on the discursive construction of subjectivities and the collective identity of the "Brazilian nation", as well as on the political consequences of certain speeches and practices regarding identity, security and mobility, taking as a methodological contribution discourse analysis. In this sense, investigating representation strategies performed by the Brazilian Army that transform the threatening spectacle of the "flood, invasion of refugees" into a compassionate stage of care, benevolence becomes central to this article, as well as exposing the migratory vulnerability experienced in this process.

KEYWORDS: migrations; identities; armed forces; borders; operação Acolhida.

\section{Introdução}

A complexidade e multiplicidade dos fluxos migratórios ao redor do mundo vem desafiando as estruturas estatais e o termo crise migratória, em específico, vem mobilizando alarmes quanto ao dever humanitário de salvaguardar os direitos dos indivíduos que necessitam atravessar fronteiras e quanto a periculosidade, invasão de "potenciais terroristas ou desviantes".

Nesse sentido, as fronteiras entre Estados tornam-se o lócus de exercício de soberania, militarização, performatividade de identidade de uma determinada comunidade política em relação a outra. Partindo da concepção de fronteiras não apenas como muros, arames farpados ou como circunscriçóes territoriais que controlam o fluxo de mercadorias e indivíduos, mas como elementos subjetivos, discursivos, reforçados cotidianamente (FOUCALT, 1996, 2008a, 2008b; CAMPBELL, 1992; DOTY, 1996). 
$\mathrm{O}$ artigo busca investigar de que maneira a constante utilização do termo "crise de refugiados venezuelanos" funciona demandando determinadas ações emergenciais brasileiras e criando, por conseguinte, latentes fronteiras coletivas dentre os papeis dos militares brasileiros e os papeis que devem ser desempenhados pelos refugiados venezuelanos acolhidos.

Assim como Huysmans (2006) expóe, o ponto central aqui não é abordar o valor ético e político das fronteiras abertas para os refugiados em termos normativos, mas entender como as práticas de segurança e insegurança estão ligadas a certas imaginaçóes da localização e da natureza da comunidade política que circundam esses indivíduos e os tornam refugiados. Dessa maneira, o objetivo principal do artigo é problematizar as dinâmicas discursivas utilizadas pelos órgãos governamentais e militares da "Operação Acolhida ${ }^{2}$ ". Com esse questionamento em mente, urge-se refletir de que forma discursos de perigo e controle das fronteiras coexistem em uma lógica de acolhimento e defesa dos direitos humanos, materializando-se na fronteira Brasil-Venezuela.

Embora o artigo parta do recrudescimento do fluxo migratório venezuelano no final do ano de 2017, pretende-se aprofundar a discussão nos desdobramentos políticos e discursivos que engendraram na criação da Operação Acolhida, em março de 2018. Ademais, o artigo, de forma incipiente, propóe uma reflexão crítica sobre como os agentes discursivos - nesse caso, políticos e militares - constituem-se com conhecimento autoritário sobre problemas políticos - lê-se aqui o fluxo migratório venezuelano.

Por conseguinte, a fim de compreender a governança humanitária no fluxo migratório venezuelano através da Operação Acolhida e a interseção de mobilidade e identidade, o artigo será estruturado em duas seçóes, precedidas por esta Introdução. A primeira seção salienta o panorama geral de como a "crise de refugiados venezuelanos" foi sendo inflada pela mídia e no debate público brasileiro; e como a demanda por gestão, mediação, assimilação e integração possibilitou a atuação dos militares no contexto elencado.

A segunda seção examina o enquadramento estético das imagens de publicidade divulgadas na Operação Acolhida, a fim de entender como a reprodução de determinadas identidades como homogêneas, unitárias e consistentes geram

\footnotetext{
2 Por meio da Medida Provisória no 820, de 15 de fevereiro de 2018, o Brasil instituiu o Comitê Federal de Assistência Emergencial, que decretou emergência social e dispôs de medidas de assistência para acolhimento a esse segmento-alvo (BRASIL, 2018). Os Decretos n 9285 e nº 9286, da mesma data da Medida Provisória, constituem parte da legalidade e da amplitude impostas aos atores comprometidos com essa ação. Em março de 2018, a ForçaTarefa Logística Humanitária que coordena a Operação Acolhida foi lançada pelo governo federal, colocando como objetivo central: lidar com o "caos humanitário" instalado nas cidades de Boa Vista e Pacaraima- ambas localizadas no estado de Roraima - através de três pilares de atuação: Ordenamento da Fronteira; Abrigamento e Interiorização.
} 
um sentimento de segurança, sendo perpassada por uma política discursiva que sempre articula um Eu e um outro (HANSEN, 2006; CAMPBELL, 1992).

É necessário evidenciar que as indagaçôes propostas nesse artigo são frutos de pesquisas prévias em artigos científicos, matérias jornalísticas sobre a migração venezuelana, indagaçôes teóricas e do meu breve contato com os abrigos e com a Operação Acolhida em Boa Vista e Pacaraima e que, portanto, não busco estabelecer uma "verdade" sobre um frutífero mundo de vivências subjetivas, psicológicas, políticas e sociais dentro dos abrigos e entre os refugiados e militares. Pelo contrário, busco expor minhas impressóes, incipientes indagaçóes, incômodos, dúvidas, contestações em relação a um sistema de proteção e abrigamento que recebe inúmeras demandas, dificuldades, almeja se adaptar para prover um melhor atendimento a essa população vulnerável mas que de certa medida, por enfocar em ordem, estabilização através de um humanitarismo militarizado, acaba reforçando características problemáticas para uma prolífica vivência, integração dos refugiados no cenário local.

$\mathrm{O}$ artigo busca desenvolver teórica e metodologicamente uma reflexão pós estrutural pautada na análise de discurso ${ }^{3}$ - com autores como Campbell (1992, 1996, 1998), Bialasiewictz (2007), Jackson (2005), Connoly (2002) e, mais especificamente, Hansen (2006). Assim sendo, o enfoque analítico do artigo está nas mobilizaçôes discursivas dos políticos e militares partindo da noção de intertextualidade ${ }^{4}$ explorada por Hansen (2006), que salienta a necessidade política, empírica e analítica de tomar textos oficiais de política externa e de órgãos atrelados ao governo - declaraçôes, discursos e entrevistas - não como entidades que se separam de discursos sociais mais amplos, mas como entidades localizadas dentro de uma encadeamento textual maior: indo para além de textos explicitamente de política tradicional, observando recortes jornalísticos, enfocando na estética e em sua potencialidade política.

Baseando-se em como Jackson (2005) analisa a linguagem da Guerra ao Terror empregada para justificar e normalizar uma campanha global de violência, o artigo almeja olhar para a linguagem brasileira no tocante ao fluxo venezuelano, trabalhando com termos como hospitalidade, Mão amiga, acolhimento corrente no imaginário brasileiro - e a hostilidade -remetendo a palavras como

\footnotetext{
3 Parte-se da noção de uma análise de discurso que possibilite compreender como tanto a nível subjetivo quanto o material, linguístico e não linguístico,os discursos são performativos, ou seja, constituem os objetos e identidades de que falam (BIALASIEWICZ, 2007).

${ }_{4}$ Primeiramente cunhado por Kristeva, que considera que "a noção de intertextualidade substitui a noção de intersubjetividade quando percebemos que o significado não é transferido diretamente do escritor para o leitor, mas sim mediado por, ou filtrado por, "códigos" transmitidos ao escritor e ao leitor por outros textos" (KRISTEVA, 1980, p.66, tradução minha).
} 
crises, ondas, perigos, braço forte, gestão logística- como estratégia política para reforço de uma identidade que é instável, precária e portanto, precisa ser constantemente remodelada 5 .

Por conseguinte, a discussão teórica aqui pretendida toma como parâmetro a proposição de que a linguagem "é um conjunto deliberada e meticulosamente composto de palavras, suposiçóes, metáforas, formas gramaticais, mitos e formas de conhecimento - é um discurso cuidadosamente construído" (JACKSON, 2005, p. 2, tradução minha).

Atrelado a análise de discurso e a intertextualidade, o artigo pretende contar com o estudo de mediação (BOLTANSKI, 1999; CHOULIARAKI, 2006) que traz à tona como a mídia, o discurso e a imagem se conectam, o que para Silverstone (2004) significa priorizar às instituiçóes e tecnologias por meio das quais a circulação do discurso da notícia ocorre.

Dessa forma, propóe-se pensar de que forma a Operação Acolhida, através de seu braço militar, traz consigo uma política discursiva utilizada para capturar "coraçôes e mentes". Essas estratégias de discurso — o que Boltanski (1999) chama de "política da piedade", termo primeiramente cunhado por Arendt (2006) utilizam a televisão, matérias jornalísticas, de modo a tornar o espetáculo de sofrimento não apenas compreensível, mas também eticamente aceitável para o espectador. Assim, embora matérias de conteúdo online, jornais impressos, vídeos, imagens sejam diferentes e possuam especificidades, o artigo parte da noção de que ambas as formas midiáticas abordam uma narrativa verbal e não verbal (descrição, narração ou exposição), no qual uma lógica de sofrimento é valorizada. Mais do que isso, a escolha desse arcabouço discursivo foi feita devido a multimodalidade existente entre elas (CHOULIARAKI, 2006). Em outras palavras, a escolha de diversas formas linguísticas se deu para evidenciar de maneira veemente como em cada uma delas, em diferentes formatos, sentimentos são induzidos de uma forma particularmente poderosa. Essas representações abordam questóes políticas e oferecem ao espectador uma experiência que atrela medo, insegurança, pena, enquadrando politicamente um senso de identidade e comunidade ao fluxo migratório venezuelano (JOHNSON, 2011; BLEIKER, 2018; DEBRIX; WEBER, 2003).

\footnotetext{
5 A segurança aqui prabalhada também se dá em termos discursivos: "então o que é segurança? Com a ajuda da teoria da linguagem, podemos considerar "segurança" um ato de fala. Nesse uso, a segurança não interessa como signo que se refere a algo mais real; o enunciado em si é o ato. Ao dizê-lo, algo é feito (como apostar, fazer uma promessa, nomear um navio). Ao proferir "segurança", um representante estadual move um determinado empreendimento para uma área específica e, portanto, reivindica o direito especial de usar todos os meios necessários para bloqueá-lo.” (WÆVER, 1995, p.55, tradução minha).
} 
A mediação é fundamental por configurar como uma técnica de conexão ou distanciamento de significado, contribuindo para um conjunto de crenças, normas, instituições e identidades em qualquer sociedade. Ademais, a mediação mantém os significados e relaçóes sociais que se estabelecem entre sujeitos e objetos em diferentes contextos sociais. (DEBRIX; WEBER, 2003). Essa questão midiática e visual aqui trabalhada, portanto, torna-se uma forma de expor as práticas e um dado posicionamento da Operação Acolhida

Tendo em vista esses caminhos metodológicos e teóricos, é importante frisar que os posicionamentos aqui defendidos não almejam determinar a autenticidade ou não de histórias, discursos, identidades, mas expor como as mesmas dependem da coação de crises internas para o estabelecimento de homogeneidades e continuidades e para sua problematização, desconstruçóes. Por fim, espero que essa incipiente discussão não essencialize os processos sociais existentes, nem faça juízo de valor quanto ao caráter, às intencionalidades dos militares os quais tive contato, mas possibilite posteriores discussóes acerca das tensóes existentes entre discursos e a governança humanitária observada.

\section{O despertar político-midiático para a chegada da crise venezuelana no Brasil: uma arquitetura simbólico-discursiva do acolhimento}

A Venezuela enfrenta um dos panoramas mais conturbados político e economicamente de sua história, circundada por escassez de alimentos e medicamentos, uma contração do PIB de 7,4\% — completando quatro anos consecutivos de queda do PIB nacional - e projeçóes apontando para hiperinflação em 2018, indo de 720,5\%, em 2017, para 2.068,5\% no ano seguinte de acordo com o Fundo Monetário Internacional, quando questionado pelo Diário de Notícias (TAXA..., 2018). Apesar das nefastas consequências desse quadro instável terem atingido seu ápice somente nos últimos anos, o estopim dessa situação ocorreu no fim do século XX, mais especificamente nos anos 1980 e 1990 . Dessa forma, o movimento de venezuelanos para fora do país devido a um cenário de crise econômica remonta à década de 1980 (PEDROSO; JAROCHINSKI SILVA, 2019) mas no final de 2016 e início de 2017 essa situação ganhou repercussões no cenário brasileiro ${ }^{4}$.

Tomando como base dados do Alto Comissariado das Naçóes Unidas para os refugiados (MANZI, 2020), o mundo tinha no fim de 2019, cerca de 79,5 milhóes de pessoas forçadas a deixarem suas regióes de origem por motivos de guerra, violência, perseguição e violação de direitos humanos, sendo o 
maior valor registrado desde a criação do órgão, em 1950. Segundo o relatório ${ }^{6}$, o número de refugiados em todo o planeta dobrou em apenas 20 anos e cresceu em 2,3 milhões de pessoas em relação a 2017, contabilizando cerca de 26 milhóes de refugiados. Desse total, 68\% ou mais de dois terços dos refugiados vem de cinco países: Síria (6,6milhões), Venezuela (3,7milhóes), Afeganistão (2,7 milhôes), Sudão do Sul (2,2 milhôes) e Mianmar (1,1milhóes) (ACNUR, 2020). Um grande fluxo migratório nas Américas que mobilizou órgãos internacionais desenvolve-se a partir de 2017, na Venezuela, atingindo repercussóes internacionais. Fugindo principalmente de grave e generalizada violação de direitos humanos, perseguição política, o fluxo de venezuelanos e venezuelanas é o maior êxodo da história recente da América Latina e Organização das Naçóes Unidas estima que mais de 4,7 milhóes de venezuelanos já deixaram seu país de origem (ACNUR, 2020). Esse fluxo venezuelano marcou especialmente o Brasil, por ter sido o momento de maior número de solicitaçóes de refúgio desde o começo da série histórica do Comitê Nacional para os Refugiados (Conare), do Ministério da Justiça ${ }^{7}$ sendo cerca de 173.000 venezuelanos que encontram-se no Brasil de acordo com dados do relatório da Fgv Dapp ${ }^{8}$ (2018).

Tendo em vista os números alarmantes, a questão venezuelana torna-se um tema dentro da pauta brasileira, sendo construído e reproduzido pela mídia brasileira, tanto em matérias em revistas eletrônicas, quanto em jornais televisivos, no final de 2016 e desenvolver de 2017 . O rótulo de crise, onda, enxurrada de refugiados, enfocando em números e pensando em termos de perigo, desordem, caos, como pode ser percebido nas manchetes a seguir, com grifo da autora: Venezuelanos levam o caos a Roraima (ROXO, 2016); Invasão venezuelana gera caos em Roraima (TOLEDO; KNAPP, 2016); Migração em massa de venezuelanos muda a realidade do lado brasileiro da fronteira (MIGRAÇÃO..., 2017); Invasão de venezuelanos em Boa Vista causa a expansão do "portunhol"

\footnotetext{
6 Os dados numéricos são relevantes de serem salientados pois é através deles que a questão venezuelana torna-se um assunto incontornável e emergencial, chamando a atenção de inúmeras organizações internacionais e países para a América Latina. Nesse sentido, apesar da bancada política valorizar o aspecto humanitário da nação brasileira através da Operação Acolhida, é forçoso ressaltar que o início da Operação se deu em termos de defesa e controle da fronteira. Os dados numéricos são relevantes de serem salientados pois é através deles que a questão venezuelana torna-se um assunto incontornável e emergencial, chamando a atenção de inúmeras organizações internacionais e países para a América Latina. Nesse sentido, apesar da bancada política valorizar o aspecto humanitário da nação brasileira através da Operação Acolhida, é forçoso ressaltar que o início da Operação se deu em termos de defesa e controle da fronteira.Se esses dígitos estivessem circunscritos a um território, superariam a população francesa e tailandesa, podendo formar o $20^{\circ}$ país mais populoso do mundo (ACNUR, 2018).

7 Foram 33.865 solicitações contabilizadas em todo o país,sendo quase o triplo dos pedidos registrados em 2016 (uma alta de 228\%). Antes, o recorde de solicitações tinha sido alcançado em 2014, quando houve 28.670 requerimentos de estrangeiros (CONARE, 2018).
}

8 FGV Dapp é a sigla para Fundação Getúlio Vargas Diretoria de Análise de Políticas Públicas. 
(INVASÃO..., 2017); Onda de imigrantes da Venezuela pode gerar crise em Roraima (BOADLE, 2017); Crise quintuplica número de imigrantes venezuelanos no Brasil (CRISE..., 2017); Autoridades de Roraima pedem "socorro" para lidar com imigração e querem interiorização de venezuelanos (COSTA; BRANDÁO; OLIVEIRA, 2018b) ${ }^{9}$.

Com esses dados, há uma "política dos números" que alimenta a percepção do excesso (AGUIAR, 2019, p.27) e cria um senso de perigo, superlotação dos serviços básicos que recrudesce os casos de xenofobia em um município de pequenas proporçóes, que é Pacaraima, localizada na fronteira entre a porção brasileira e a venezuelana, na cidade de Santa Elena de Uairén.

Por conseguinte, Pacaraima pode ser lida como esse local de desconforto e conflito entre identidades e é retratada como um "barril de pólvora por causa de refugiados da Venezuela” segundo manchete do G1 (COSTA; BRANDÃO; OLIVEIRA 2018a). Complementando essa visão de desordem e caos, em 2018, a prefeita de Boa Vista (RR) Teresa Surita afirmou em entrevista à BBC (MORI, 2018) que "até o fim do ano, perderá o controle da cidade". Nesse sentido, a crise migratória contemporânea constitui-se como um dos grandes temas da política internacional, trazendo questóes como o humanitarismo das naçóes e no vértice oposto, a rigidez do Estado soberano e a conexão entre território, população e manutenção da segurança que ainda circunda a imaginação política global. Segundo Aguiar (2019, p.31) "a ideia de uma crise migratória envolve o reconhecimento da instabilidade das fronteiras como marcadores geográficos e temporais das relaçóes de pertencimento contemporâneas. Nyers (2006) evidencia que, ao mesmo tempo que refugiados são vistos como uma "emergência humanitária”, passam a ser cada vez mais engendrados como causadores de uma crise global sem precedentes, sendo objetos de veemente preocupação política.

A construção da questão do refúgio e do deslocamento de pessoas assume uma chave de 'problema' e 'emergência' no plano internacional (NYERS, 2006), estando os indivíduos que não se encaixem no modelo essencial de cidadão fadados a rótulos como "acidentais e abjetos". Dessa forma, ao converter o termo fluxo migratório em uma "crise", uma rivalidade identitária é acentuada:

\footnotetext{
9 As mídias aqui expostas embora tratadas de forma homogênea,possuem suas menoridades e especificidades, que não serão aprofundadas aqui.Parte-se das semelhanças entre essas mídias e de como elas contribuem para uma política da piedade (BOLTANSKI, 1999; ARENDT, 2006), evidenciando o senso comum que criam no âmbito social de desordem e caos e ao mesmo tempo, pena e compaixão. Ver mais em : "as imagens funcionam em vários níveis sobrepostos: além das fronteiras nacionais e entre o mundo físico e o mental. Eles vêm em variedades complexas e amplas: como fotos ou filmes, como quadrinhos ou videogames. As coisas ficam ainda mais complexas quando pensamos em artefatos visuais tridimensionais, como arquitetura, uniformes militares ou monumentos" (BLEIKER, 2018 , p.11, tradução nossa).
} 
"logo, o problema não é só que os refugiados e imigrantes são numerosos, mas que são muitos do 'mesmo' e que a natureza desse 'mesmo', singular e centrífugo a um conjunto de discriminaçóes raciais, étnicas e religiosas, ameaça em alguma medida amplos contingentes das sociedades hospedeiras [...]" (AGUIAR, 2019, p.30).

Aliada a essas construçôes discursivas que enfocam nos riscos, no grande volume de indivíduos adentrando o território brasileiro, que encontra-se "vulnerável”, uma política estética também é mobilizada: através da predominância de imagens estereotipadas de pessoas amontoadas nas calçadas, filas gigantes, superlotando hospitais, escolas, praças, afetando postos de trabalho, elementos que seriam obstáculos para a segurança física e manutenção de uma vida digna e "confortável" dos cidadãos nacionais.

Nesse sentido, observa-se como essas imagens moldam a opinião pública e o tipo de práticas e decisóes que fundamentam as comunidades políticas (BLEIKER, 2018).

Johnson (2011) ressalta como os refugiados passaram a ser retratados como vítimas, sem agência política, entendidos como perigosos, problemáticos e carentes de correção, uma vez que o cidadão é a norma. Segundo a autora, a vitimização do refugiado ocorre por meio do discurso representacional, seja através de sua representação visual ou verbal (JOHNSON, 2011).

Além disso, a partir da técnica de mediação - já exposta na introdução - torna-se notório que as chamadas crises humanitárias não possuem um significado naturalmente dado. As crises são constituídas de uma maneira específica (DEBRIX; WEBER, 2003).

Observa-se, portanto, que "problemas" atrelados a esse "crise" começam a ser relatados e noticiados nas cidades de Boa Vista, Pacaraima, que por estarem em uma área de baixa densidade populacional, com serviços públicos de baixa qualidade, com dificuldades de integração com o resto do território nacional, acabam utilizando os venezuelanos recém chegados como bodes expiatórios de questôes que tradicionalmente já existiam na sociedade (GREENSLADE, 2005). De acordo com Sarmento e Rodrigues (2018) associação automática entre migração venezuelana e o recrudescimento das mazelas em Roraima tornou-se comum, sendo "um recurso narrativo através do qual os moradores locais demonstram frequentemente sua insatisfação com o acolhimento desses migrantes, ainda que esta correlação seja fortemente questionável" (SARMENTO; RODRIGUES, 2018, p.242).

Com essas imagens acendendo um caloroso debate sobre a crise, ações governamentais emergenciais são demandadas e tomadas, perpassando uma lógi- 
ca securitária ${ }^{10}$, militarizada, de salvaguarda e controle das fronteiras e da soberania nacional, como reaçáo ao que o presidente Michel Temer ressaltou como um "êxodo venezuelano que perturba países da América Latina" (ÊXODO..., 2018).

Essa lente securitária — no qual os refugiados estão inseridos —é relevante por evidenciar dinâmicas de poder, marginalização, mobilização de símbolos e identidades, norma e exceção e é bem sumarizado por Balzacq (2010, p. 3) em:

Eu defino securitização como uma montagem articulada de práticas por meio das quais artefatos heurísticos (metáforas, ferramentas de governo, repertórios de imagens, analogias, estereótipos, emoçóes, etc.) são contextualmente mobilizados por um ator securitizador, que trabalha para estimular um público a construir uma rede coerente de implicaçóes (sentimentos, sensaçóes, pensamentos e intuições), sobre a vulnerabilidade crítica de um objeto de referência, que concorre com as razóes das escolhas e açóes do ator securitizador, ao investir o sujeito referente com tal aura de inédito ameaçadora de que uma política personalizada deve ser adotada imediatamente para bloquear seu desenvolvimento (BALZACQ, 2010, p. 3, tradução minha).

Nesse processo de construção do inimigo nacional, as minorias e os adversários políticos são desumanizados (SARMENTO; RODRIGUES, 2018), constituídos como ameaças através da mobilização de valores, tradiçóes, informaçóes comuns a uma dada "identidade". Por consequência, deve-se conter, expulsar, eliminar as diferenças existentes nesses outros, possibilitando açóes desde marginalização, violência verbal e violência física, ou seja, efeitos práticos da construção dessa periclitante alteridade (BALZACQ, 2010; CAMPBELL, 1992; HANSEN, 2006).

Portanto, esse movimento conceitual trazido pela securitazação, atrelado ao pós estruturalismo é fundamental no artigo para demonstrar de que forma através de uma política discursiva, há um reforço de identidade dita nacional

\footnotetext{
${ }_{10}$ É fundamental ressaltar que o artigo refere-se a securitização, conceito primeiramente cunhado por Wæver, Buzan, Wæver em 1998 e entendido aqui como um movimento conceitual amplo que busca problematizar como qualquer questão pode ser transformada em termos de segurança por determinado ator, permitindo o uso de medidas extraordinárias. Os autores argumentam que os estudos de segurança precisam adotar uma compreensão da "dualidade" da segurança: que combina a segurança estatal e preocupação com soberania com a segurança social, com enfoque na segurança da identidade dos indivíduos. Dessa forma, almejam estudar o processo pelo qual as ameaças são representadas politicamente: examinar quem pode fazer ou falar de segurança com sucesso, em que condições e com quais efeitos, sempre ressaltando o conjunto particular de discursos e práticas históricas que repousam sobre entendimentos institucionalmente compartilhados (BUZAN et al., 1998).
} 
e diferenciação dos outros—que seriam os que adentram o território brasileiro vindo da Venezuela -

Através da instrumentalização da dicotomia "eu-outro", que atende as necessidades estatais em construir "discursos de perigo ", visa-se fornecer uma nova teologia da verdade sobre quem e o que 'nós' somos, consequentemente delimitando quem ou o que 'nós' não somos, e o que temos a temer e destruir.

Nesse sentido, o ator securitizador para se solidificar, - nesse caso o governo brasileiro - evitar ameaças externas e manter uma coesão interna, cria discursos que colocam o outro como perigoso, desordeiro, inumano tornando consequentemente, o nacional dependente de proteção, que por sua vez, incorpora consciente e/ou inconscientemente um sentimento patriotista/belicista. Em suma, observar essa conexão entre segurança e identidade é fundamental para a conexão entre o macro e o micro, para o entendimento de como indivíduos baseiam-se em estruturas coletivas para definição de suas identidades individuais e vice-versa.

$\mathrm{Na}$ prática, isso pode ser evidenciado através do envio de efetivos maiores de duas centenas de homens do Exército bem como de equipes da Polícia Federal (BRASIL..., 2018), tentativa de suspensão do ingresso e admissão dos refugiados (PEDUZZI, 2018), estabelecimento de cotas de acesso venezuelano ao Brasil, controle das fronteiras e negação de acesso a serviços públicos básicos proposto pela governadora do estado de Roraima (NUNES, 2018), um quadro de contenção, inspeção e vigilância da mobilidade humana vai se consolidando (MACHADO, 2018), configurando o que Pedroso, Jarochinski Silva (2019) chamam de "xenofobia institucional".

No estabelecimento prévio da relação hierárquica entre Estado - cidadão território, o refugiado não se encaixa, sendo considerado, portanto, como um elemento desviante que pode enfraquecer essa tríade (HADDAD, 2008), o que, na chave de pensamento de Schmitt (2008), estaria na essência da política: nessa constante luta contra o oponente, em uma divisão de mundo entre amigos e inimigo, insider-outsider.

Assim sendo, observa-se um tratamento da temática de mobilidade voltado para a ameaça, para a divisão entre "nós" (homogêneos, cidadãos) e os outros (refugiados venezuelanos). Essa percepção de invasão e necessidade de reafirmação da identidade, cidadania brasileira frente aos refugiados venezuelanos, é uma tentativa de ordenamento, legitimação de uma identidade coesa frente a uma alteridade ameaçadora (OLSSON, 2016).

A migração venezuelana, por conseguinte, traz à tona a insegurança em tempos de crise articulada, junto com a necessidade de reafirmar a identidade através de modulaçôes discursivas. Ademais, segundo Milesi, Coury e Rovery 
(2018), a gestão do fluxo migratório de venezuelanos para o Brasil tem representado um desafio, no qual o Estado constitui um ciclo vicioso de controle e diferenciação, o qual tem resultado no crescimento das manifestaçóes de xenofobia, com grande prejuízo para a população migrante (MILESI; COURY; ROVERY, 2018; DURÃES; JUNIOR, 2018; SARMENTO; RODRIGUES, 2018).

Dos Santos Vasconcelos (2018) e Camargo e Hermany (2019) apontam que a operação inédita do Exército, cuja missão é gestão humanitária combina elementos como ordenamento e controle, lei e ordem, afeto e amizade, que em linhas gerais, exprimem que proteger, inspecionar e vigiar o migrante funciona como justificativa e gramática moral para reprimir os fluxos migratórios e exacerbar a linguagem do acolhimento.

Observa-se, portanto, a conceituação da fronteira como um instrumento de identidade, controle e poder (FOUCAULT, 1996, 2008a, 2008b; AGAMBEN, 2009). Assim sendo, diferentemente de uma divisão dada, que existe ad aeternum, a fronteira concebida aqui entre os refugiados venezuelanos e os cidadãos brasileiros faz parte de um projeto de política, a todo momento performatizado, que traça disputas, diferenciaçóes entre um estatal e um outro.

Portanto, essa "política do movimento" (AGUIAR, 2019) disciplina e tenta gerenciar o fluxo de indivíduos que possuam elementos que desestruturem seu senso de pertencimento e completude identitária, retomando a autoridade sobre os territórios. Essas fronteiras ${ }^{11}$ mobilizadas são constitutivas na vida política, estando relacionadas às lógicas de dentro e de fora, práticas de inclusão e exclusão e questôes sobre identidade e diferença (VAUGHAN-WILLIAMS, 2009).

Assim, segundo Vaughan-Willliams (2009) a fronteira passa a estar relacionada com a ideia de soberania, identidade autoridade estatal e violência.

Nesse sentido, pensar em discursos de poder no tocante ao refúgio é entender como a política funciona em uma lógica do "poder ético de segregação", realizando distinçóes morais dentre o dentro e o fora, o forte/fraco, o racional/ irracional (CAMPBELL, 1992), colocando os refugiados como desvios:

A falta de moradia é uma séria ameaça ao comportamento moral [...] No momento em que o refugiado atravessa as fronteiras de seu próprio mundo, toda sua visão moral, sua atitude em relação à ordem divina de vida muda ... A conduta [dos refugiados] deixa claro que estamos lidando com indivíduos que são basicamente amorais, sem qualquer sentido de

\footnotetext{
11 Ver mais em Williams (2006) que conceitua as fronteiras dos Estados como onipresentes e inerentes a política internacional por serem parte da faceta da existência humana.
} 
responsabilidade pessoal ou social [...] (CIRTAUTAS, 1957, p.70, tradução minha).

Embora Campbell (1992) trabalhe com a questão de política externa, o autor deve ser ressaltado por investigar de que forma a relação "performática" entre identidade/diferença é fundada no estabelecimento de demarcaçôes entre eu/outro, interno/externo, doméstico/estrangeiro. Em outras palavras, Campbell (1992) deve ser inserido na discussão de mobilidade por tecer indagaçóes sobre como a política externa funciona como prática de produção de fronteiras, nas quais as identidades são frutos da operação do poder e materializadas através do discurso.

Assim sendo, as dinâmicas evidenciadas pelos militares, permitidas e reforçadas pelo aparato governamental brasileiro quanto a logística humanitária da população venezuelana abrigada é um reflexo de como o nexo identidade/diferença é produzido: através de processos e discursos de ligação e diferenciação, que procuram estabelecer a estabilidade. No entanto, esses discursos e práticas que buscam reforçar uma "identidade" conciliadora, acolhedora do Brasil são compostos por elementos ambíguos e relacionais, que devem ser constantemente questionados e, por conseguinte, desconstruídos (HANSEN, 2006).

Dessa forma, o artigo parte da abordagem do Campbell, que enfoca na política externa, mas a utiliza para analisar no momento em que a identidade dos Estados é "constituída” discursos de perigo e diferença e instrumentos político-discursivos são performatizados.

Portanto, é precisamente porque os Estados estão sempre em construção, que podem se engajar em um evangelismo do medo, por meio de discursos de perigo, para tentar assegurar uma identidade precária e provisória, sendo o "outro" do lado de fora um aviso para os diferentes domésticos (CAMPBELL, 1992).

Em tempos de incerteza, ruptura governamental, transformação política, o Brasil - analogamente aos EUA - precisou contar com uma robusta plataforma identitária para promover um senso de estabilidade e esperança, se "reiventando" como nação. Nesse sentido, com a entrada do presidente Bolsonaro e os novos ministros na gestão do país, houve uma "construção ambivalente da intervenção pública” (NINOO, 2018, p.131) na temática de migração, haja vista que concomitante a avanços para garantir direitos dos migrantes, algumas medidas restritivas foram adotadas, desencadeando retrocessos para o direito internacional para migrantes e refugiados e para os direitos humanos. 
Segundo Niño (2018) a chegada massiva de venezuelanos no Brasil coincide com um contexto de deterioração institucional, político- econômica do Brasil, que foi exacerbada após o impeachment da presidenta Rousseff e com a chegada do governo interino de Michel Temer, que transformou a orientação de várias políticas governamentais, incluindo a política social e a política externa, o que tem afetado a resposta brasileira à migração venezuelana. Tendo isso em vista, a retórica da crise migratória reverbera, tornando o "lugar" da Venezuela como problema e outro enquanto o Brasil faz parte da "solução".

Assim sendo, pensando a fronteira nesse primeiro momento como encontro da identidade com a diferença (VAUGHAN-WILLIAMS, 2009), no instante em que os venezuelanos atravessam esses espaços de separação do exercício de uma soberania estatal frente a outra, são vistos como ameaças à coesão homogênea interna, oriundos de um caos ideológico, tendo que ser "controlados" de forma a não romperem com a ordem do Brasil.

Dessa forma, o rótulo de crise torna-se factível e bem acurado, tendo em vista a definição de crises como eventos ocorridos no momento em que a construção de uma determinada ordem social não consegue preservar um senso de segurança, de identidade do Estado (CAMPBELL, 1992).

Em outras palavras, o vocabulário de "crise" (NYERS, 2006) passa a gerar um senso de obrigação moral acoplado com ideais discriminatórios e xenofóbicos. Ademais, é fundamental ressaltar como essas performances estatais frente a crises dependem de determinadas conjunturas políticas, econômicas, apoio estético e discursivo de veículos midiáticos, mobilizando sua identidade como:

[...] O resultado de práticas excludentes em que elementos resistentes a uma identidade segura no 'interior' são ligados por um discurso de 'perigo' a ameaças identificadas e localizadas no 'exterior'. O resultado disso é que fronteiras são construídas, espaços demarcados, padróes de legitimidade incorporados, interpretaçóes da história privilegiadas e alternativas marginalizadas (CAMPBELL, 1992, p.75, tradução minha).

Embora a conceituação da identidade como discursiva, política, relacional e social implique discursos de alteridade (HANSEN, 2006), essas identidades não são necessariamente construídas através da justaposição a um Outro radicalmente diferente e ameaçador (CAMPBELL, 1992).

Torna-se forçoso explicitar a conexão entre os estudos críticos de segurança e o processo de securitização aqui abordado partindo dessa proposição, observa-se que os refugiados venezuelanos podem ser tratados sob um enfoque 
securitário $^{12}$, de análise de risco, controle e militarização de fronteiras ao mesmo tempo em que passam a ser representados como vítimas, irmãos latino-americanos, com uma alteridade que está no entre lugar do vizinho que necessita de auxílio e de uma potencial ameaça caso não seja "ordenado e incorporado" no enquadramento social brasileiro.

Dessa maneira, "como as diferentes refraçóes de luz de um mesmo caleidoscópio, o espetáculo nacional de vigilância, policiamento e controle de fronteiras é também o espetáculo cosmopolita de resgate e salvação" (MUSARÒ, 2016, p.16, tradução minha). Assim sendo, imagens de sofrimento, ausência de comida, prostituição de mulheres e adolescentes, crianças $^{13}$ chorando passam a inundar os noticiários, trazendo manchetes com palavras como drama, fuga da fome, descrevendo o cotidiano sofrido dos venezuelanos, em uma lógica de piedade, compadecimento, demandando açôes mais assertivas dos órgãos governamentais (CRISE NA VENEZUELA..., 2017; O DRAMA..., 2018; COSTA; BRANDÃO; OLIVEIRA, 2018a; LUZ, 2017). Percebe-se que essa política discursiva consegue mobilizar o apoio público e a preocupação com a situação dos refugiados dentro de um discurso humanitário e, ao mesmo tempo, é capaz de "lidar" com a ameaça de instabilidade e diferença apresentada pela condição dos refugiados (JOHNSON, 2011).

Segundo Boltanski (1999) essa narrativa de piedade se deve pelo enfoque midiático ${ }^{14}$ e os efeitos 'espetaculares' que ele produz, em como o desejo de recorrer à comunidade e, mais profundamente, por um ceticismo em relação a qualquer forma de ação política orientada para um horizonte de ideais morais. Contudo, de acordo com o autor, o sofrimento de minorias e estrangeiros náo é levado em consideração, haja vista que são considerados responsáveis por seus males e considerados perigosos para a comunidade (BOLTANSKI, 1999).

\footnotetext{
${ }^{12}$ No tocante ao enfoque securitário, os autores entendem por segurança como "o movimento que leva a política para além das regras estabelecidas do jogo e enquadra a questão como um tipo especial de política ou acima da política. A securitização pode, portanto, ser vista como uma versão mais extrema de politização" (BUZAN et al., 1998, p. 23, tradução minha).

${ }^{13}$ Importante frisar que as imagens de crianças exercem um forte papel de mobilização do público e suas emoções, uma vez que crianças são inocentes e alimentam "narrativas pré-existentes", gerando ação política (BLEIKER, 2018).

${ }^{14}$ Boltanski define melhor esse processo com a citação: "em relação à mídia, o espectador ocupa a posição (descrita no final do capítulo 3) de alguém com quem uma proposta de compromisso é feita. Um espectador diferente, que lhe conta uma história, e que pode ser um repórter, isto é, uma testemunha ocular, ou que pode ter recolhido informações supostamente provenientes de uma testemunha ocular (como no caso da agência de notícias relatos), transmite depoimentos e imagens a um espectador, que pode tomá-los e, por meio de suas palavras, transmitir por sua vez o que extraiu dessas declarações e imagens e as emoções que elas despertaram nele. Não se trata de qualquer tipo de declaração e imagem" (BOLTANSKI, 1999, p.149, tradução minha).
} 
Lidando com as veementes pressóes e críticas da sociedade civil ${ }^{15}$ e atrelado a essa nova mobilização midiática da crise de refugiados venezuelanos como passiva da benevolência brasileira, o governo passa a tomar açôes mais coordenadas com o Alto Comissariado das Nações Unidas, reduzindo burocracias para o repasse de recursos e liberando verbas adicionais ao estado de Roraima (CHARLEAUX, 2018).

Essa performance pendular e ambígua da abordagem de hostilidade/ameaça para a de hospitalidade/compaixão pode ser evidenciada no discurso do presidente Michel Temer na Assembleia Geral da ONU quando afirma que "Estima-se em mais de um milhão os venezuelanos que já deixaram seu país em busca de condiçôes dignas de vida. O Brasil tem recebido todos os que chegam a nosso território" e "[..] no Brasil, temos orgulho de nossa tradição de acolhimento. Somos um povo forjado na diversidade. Há um pedaço do mundo em cada brasileiro" (TEMER..., 2018).

Essa ambiguidade é observada quando os refugiados desafiam o ordenamento imposto pela cidadania, ou seja, questionam a soberania e a demarcação territorial do Estado, ao serem internos e externos, estando dentro da nação brasileira, mas fora do imaginário daqueles que devem ser cuidados pela nação, expressando a possibilidade do caos dentro da ordem existente (HUYSMANS, 2006).

Nesse sentido, observa-se um resgate, rearticulação do ideal humanitário que o Brasil busca desenvolver (MACHADO, 2018) ${ }^{16}$, valorizando sua posição acolhedora, com pluralidade de culturas - haja vista a histórica composição populacional baseada no movimento migratório japonês, libanês, italiano, alemão - e seu caráter vanguardista no regime internacional de proteção aos refugiados no continente de acordo com o ACNUR (2003). Através dessa arquitetura simbólico-discursiva rodeada por termos como acolhimento, hospitalidade, mul-

\footnotetext{
${ }^{15}$ Que demandavam fim de medidas como: lentidão e burocratização excessiva do processo de deferimento, acolhimento realizado em locais com carentes condições, abordagem voltada à segurança e controle de fronteiras ao invés da dimensão humanitária, confusão e incerteza nos critérios de deferimento — que ora aceitam a definição ampliada, ora negligenciam a grave e generalizada violação de direitos humanos-, dificuldade em acesso ao direito de permanência temporária e o direito ao trabalho formal e acesso aos serviços básicos, discriminação e xenofobia (MACHADO, 2018).

16 Ver mais em "o refúgio é uma política de Estado no Brasil. É um elemento importante da democracia brasileira e sua tradição de abertura. É um dos pilares da política de direitos humanos. (...) Nós esperamos aumentar as oportunidades de reassentamento no Brasil. A longa experiência do Brasil em ter um órgão tripartite em que governo, sociedade civil e ACNUR trabalham juntos em políticas para refugiados tem sido bem-sucedida. (...) O processo de integração social e econômico dos refugiados tem sido um constante desafio. Acreditamos que o engajamento de outros países em programas de reassentamento abre as portas para cooperação sul-sul. O Brasil está pronto a compartilhar sua experiência com parceiros interessados" (Arquivo do Itamaraty, Delegação do Brasil em Genebra apud MOREIRA, 2015, p. 5).
} 
ticulturalismo, defesa dos direitos humanos, o Brasil produz um "entendimento em que o engajamento com o "outro" - seja este o índio, o rebelde, o "estrangeiro" - ocorra a partir de uma lógica de conciliação, mediação, assimilação e integração" (GOMES, 2014, p.16 ${ }^{17}$ ).

Levando em conta essa concomitância e coconstituição da crise como um problema - em termos de gestão, contenção do fluxo - e como uma oportunidade para o Brasil ressaltar seu protagonismo na governança humanitária da estabilidade regional, exercendo uma liderança benigna, a próxima seção almeja investigar como essa arquitetura nacional desdobra-se através da Operação Acolhida equilibrando esforços concomitantes de auxiliar os necessitados com açôes para proteger as fronteiras nacionais dos mesmos (DE HAAS, 2007).

\section{Política visual da Operação Acolhida: construindo imagens dos militares brasileiros e dos venezuelanos acolhidos}

A Força-Tarefa Logística Humanitária que coordena a Operação Acolhida foi lançada pelo governo federal no início de março de 2018, no esforço de combater a" crise humanitária" provocada pela onda migratória venezuelana, sendo uma iniciativa que reúne 12 ministérios e órgãos federais, estadual e municipais, com duração prevista de 12 meses, que foi prorrogada até março de 2020 (RIBEIRO, 2019). Esse esforço conjunto envolve aproximadamente 600 militares da Aeronáutica, do Exército e da Marinha, cujos pilares de atuação são: Ordenamento da Fronteira; Abrigamento e Interiorização (KANAAN; TÁSSIO; SIDMAR, 2018).

Apesar das veementes críticas dentro da literatura acerca do papel dos militares em resposta a emergências humanitárias seja em desastres naturais, fluxos migratórios (ENETERIO; DA PAIXÃO ENETERIO; DA SILVA, 2019; HARKIN, 2005; HOFMANN; HUDSON, 2009) e, no caso brasileiro, apontando a "[...] característica nociva de 'militarizar a resposta humanitária" (CHARLEAUX, 2018); o enfoque dessa seção será investigar o que a divulgação de vídeos e imagens da operação revela sobre o contexto da "crise dos refugiados

\footnotetext{
${ }^{17}$ Embora a autora trabalhe com o Operação de Paz no Haiti, percebe-se insights dessa intelectual que podem ser adequadas no que tange o fluxo migratório venezuelano no Brasil, no momento em que a autora expõe que o Exército auxilia na representação de uma dada identidade brasileira, reproduzindo discursos de defesa de um sistema internacional mais pacífico, baseado em princípios como a constante defesa dos direitos humanos, negociação, elementos que buscam "organizar" o território e população. Assim sendo, analisando a atuação brasileira na MINUSTAH como componente de uma política externa que opera reproduzindo uma dada projeção pacifista do militar e do Brasil, Gomes (2014) explicita que o militar se constrói como aquele capaz de interpretar as necessidades do haitiano, e de administrá-las, estabilizando as demandas e coletividades, o que segundo o presente artigo, ocorre na gestão da Operação Acolhida.
} 
venezuelanos" e como se dá a rearticulação da relação entre o aspecto militar e humanitário do projeto.

É importante ressaltar que a interseção entre mídias, imagens e o campo de Relaçóes Internacionais proposto no artigo visa demonstrar que, ao legitimar um conteúdo discursivo baseado em vídeos, manchetes, imagens como fontes importantes para uma visão da política mundial, busca-se romper com uma dependência exclusiva e limitada de documentos diplomáticos, dados estatísticos e outras fontes consideradas "tradicionais" de conhecimento sobre o internacional (BLEIKER, 2001).

Essa dita "virada estética ${ }^{18 ”}$ nas Relaçóes Internacionais foi desencadeada por meio de duas mudanças inter-relacionadas na produção de conhecimento sobre a política mundial: a primeira alteração ocorreu na década de 1980, quando os pós-modernos começaram a desafiar os fundamentos positivistas da teoria internacional. O segundo movimento se deu nos últimos anos, quando intelectuais começaram a refletir sobre as implicaçôes da crítica pós-moderna, explorando diferentes formas de percepção da política mundial, incluindo imagens, narrativas e sons (BLEIKER, 2001; SHAPIRO, 2013).

Voltando aos detalhes da Operação, desde o seu início, soldados brasileiros começaram a produzir fotografias e vídeos sobre as atividades e características do projeto, mas o artigo investigará somente os produtos oficiais do Exército - por considerar o mesmo um dos braços das Forças Armadas mais ativo da Operação - . Outra ressalva que deve ser feita é que essas produçóes audiovisuais dos militares serão consideradas aqui não somente como artefatos materiais, mas como actantes cuja divulgação e distribuição impacta discursos públicos, formas coletivas de pensar e tomar decisôes em torno da "crise migratória” (MUSARÒ, 2016).

Partindo da observação do logo da Operação - que encontra-se abaixo no lado esquerdo - e própria a etimologia da palavra Acolhida, que nomeia o projeto, evidencia - um enfoque em "levar em consideração, receber" segundo o site Origem da Palavra (2011).

\footnotetext{
18 Para contextualizar melhor esse processo, Bleiker afirma que "virada estética reorienta nossa própria compreensão do político: engendra uma mudança significativa de um modelo de pensamento que iguala o conhecimento ao reconhecimento mimético das aparências externas para uma abordagem que gera um encontro mais diverso, mas também mais direto com o político. Este último permite interações produtivas entre diferentes faculdades, incluindo sensibilidade, imaginação e razão, sem nenhuma delas aniquilar a posição única e o insight do outro" (BLEIKER, 2001, p.509, tradução nossa).
} 
Figura 1 - Logo da Operação Acolhida

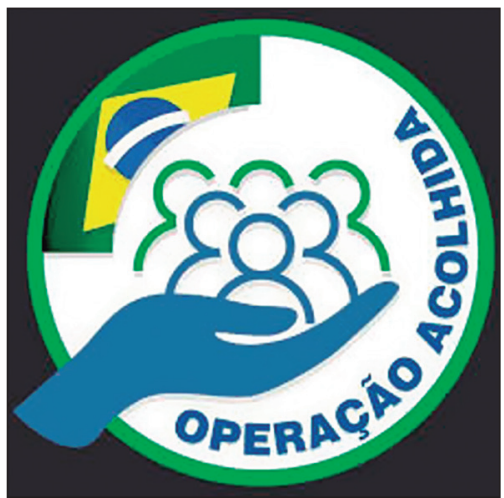

Fonte: Exército ${ }^{19}$.

A escolha da palavra "Acolhida", bem como de imagens apontando a cuidado, o conviver solidário (e a omissão de outros elementos que poderiam sugerir uma perspectiva, sentimento diferente) dos vídeos reforça uma representação particular da realidade e uma emoção específica nessa interseção de identidade e mobilidade. Entendendo as simbologias discursivas e visuais do Exército não como meras construções do campo lexical, mas circundadas por veementes intencionalidades e potencialidades em suas elaborações semânticas, essa seção do artigo começará analisando a tentativa de construção legítima do papel do Exército na condução da gestão humanitária do fluxo migratório venezuelano, que ocorre através do uso de determinadas palavras chave nos vídeos como: em busca de oportunidade, esperança, sonhos, acolhimento, proteção e principalmente a palavra mão - seja em "aperto de mãos entre crianças e soldados, são alimentadas por muitas mãos, a mão amiga das Forças Armadas e o próprio slogan do Exército Braço forte e Mão amiga que foi concebido pelo Coronel Francisco Brasil Ribeiro, utilizado nos anos 90 pelo Centro de Comunicação Social do Exército com o objetivo de "posicionar" o Exército na mente dos brasileiros - (OPERAÇÃO ACOLHIDA..., 2019; OPERAÇÃO ACOLHIDA: MUDANDO..., 2019; EM BUSCA..., 2019; OPERAÇÃO ACOLHIDA: REFUGIADOS..., 2018; OPERAÇÃO ACOLHIDA: 40 CONTINGENTE, 2019; COMANDANTE..., 2019; OPERAÇÃO ACOLHIDA: CORAL..., $\left.2019^{20}\right)$.

\footnotetext{
19 Disponível em: https://www.flickr.com/photos/oper_acolhida/with/44593254360/. Acesso em: 06 jul. 2021.

${ }^{20}$ Buscar os links dos vídeos completos em Referências Bibliográficas, na seção de vídeos.
} 
Seguindo essa lógica performática de divulgação das práticas militares, os vídeos analisados podem ser caracterizados como microcosmos políticos de uma tentativa de mobilização discursiva da identidade brasileira, no momento em que através de músicas dramáticas, desoladoras, de perigo os militares convidam os espectadores a testemunharem uma necessidade urgente de ação.

Com enfoque no caótico cenário da Venezuela, do periclitante e conturbado processo de chegada ao Brasil e travessia da fronteira, de indivíduos desassistidos, em praças, ruas, consolida-se um cenário anterior a atuação salvacionista do Exército (DOS SANTOS VASCONCELOS, 2018). Na segunda parte dos vídeos, com músicas esperançosas, o espetáculo de adrenalina dos soldados desafiando todo e qualquer obstáculo para resolver a catástrofe é substituído por depoimentos de venezuelanos agradecendo a atuação brasileira, de enfermeiras emocionadas relatando como uma nova chance foi dada a indivíduos desnutridos, debilitados e como devido a triagem, tudo mudou.

Por conseguinte, constroem-se latentes fronteiras coletivas dentre os papeis exercidos pelos militares brasileiros e os papeis que devem desempenhados pelos refugiados venezuelanos acolhidos. Nesse sentido, os discursos desempenhados pelos militares contribuem para alimentar tanto as construçóes imaginárias quanto as concretas das fronteiras, ou seja, barreiras simbólicas e políticas são encenadas e realizadas através de imagens e discursos (FOUCAULT, 1996, 2008a, 2008b; AGAMBEN, 2009; VAUGHAN-WILLIAMS, 2009).

As fronteiras aqui problematizadas são pensadas como construções que mantém a convergência de indivíduos com um determinado território e noçôes de história, nacionalidade, identidade, língua e cultura comuns, abrindo mas também limitando opulentas possibilidades políticas e éticas (VAUGHAN-WILLIAMS, 2009).

O final feliz dos vídeos, com o coro de crianças venezuelanas cantando o hino nacional rodeados por bandeiras do Brasil ou pessoas batendo palmas, sorrindo, abraçando soldados apresenta um contexto intensamente moralista que reformula a operação como sinônimo de benevolência humanitária. 
Figura 2 - Imagens do Exército
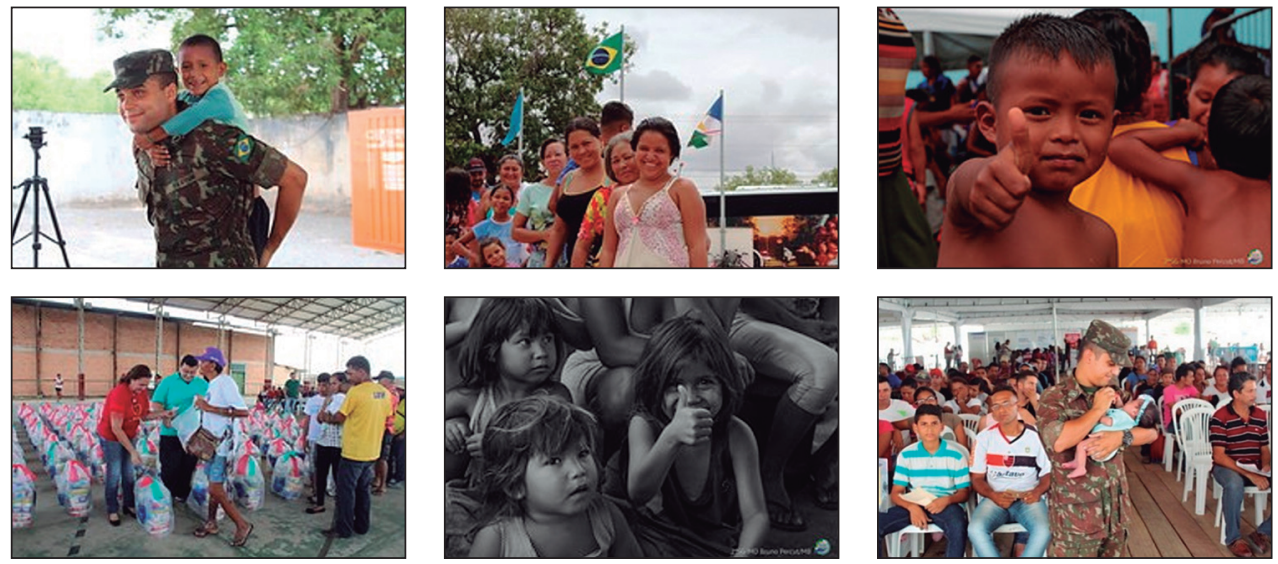

Fonte: Imagens disponibilizadas pelo Exército ${ }^{21}$.

Para além dessas imagens dos vídeos, as fotos divulgadas no site oficial do Exército seguem esse enfoque do contato direto e afetividade das crianças com os militares - representando mais da metade do total das imagens - e outras fotos da estrutura dos abrigos, de venezuelanos sorrindo, da entrega de kits higiênicos, alimentação. Pode-se depreender que os militares são retratados nesse sentido dentro de um discurso de notícias que constrói o imperativo moral de salvar vidas, destacando a eficiência dos mesmos em ajudar: com zoom em refugiados venezuelanos resgatados e agradecidos recebendo pacotes de comida e água e crianças brincando.

Bigo (2000) é fundamental de ser ressaltado pois expóe a conexão entre segurança interna e externa por meio de uma análise do policiamento, no qual a fronteira passa a ser uma questão biopolítica, regulando a vida cotidiana dos indivíduos em uma lógica de intervenção e gerenciamento, indo além de uma questão geopolítica:

O cerne desta nova securitização está relacionado com os fluxos transnacionais e com a vigilância das fronteiras (físicas, sociais e de identidade), e pode ser visto como uma tentativa de redesenhar uma fronteira entre um interior e um exterior, uma fronteira diferente das fronteiras do estado (BIGO, 2000, p.172, tradução nossa).

\footnotetext{
${ }^{21}$ Disponível em: https://www.flickr.com/photos/oper_acolhida/with/44593254360/. Acesso em: 06 jul. 2021.
} 
Enfatizando práticas e discursos de cuidado, ajuda e assistência, os soldados definem e performatizam essa operação como uma benevolência nacional humanitária, criando uma comunidade na qual o espectador é posicionado como o possível salvador, enquanto os corpos resgatados são os outros constitutivos e necessários a essa identidade benigna (FASSIN, 2001, 2005).

Bigo (2006) evidencia que essa lógica de proteção trabalhada pelos militares está atrelada a noção de gestão, monitoramento e principalmente a criação de perfis sobre quem é potencial gerador de risco. A prática de proteção relaciona-se com as normas de espaço e segurança, com o direito de morar em determinado lugar e o direito de circular livremente para uns, e o oposto para aqueles que não são cidadãos.

Por conseguinte, a proteção — nos termos de Bigo (2006, p.90) — propagada pela Operação Acolhida do espaço interno vai desde a interdição simbólica, monitoramento das fronteiras, até a força militar que protege o cidadão por meio de fortalezas que "filtram" as potenciais ameaças. Nesse sentido, esse conceito refere-se não apenas à luta contra o inimigo, mas tem relação com a população de dentro, uniformizando-a e assegurando de que nenhum "desviante" encontra-se dentro do território nacional (BIGO, 2006) ${ }^{22}$.

Assim sendo, percebe-se que esse conceito de proteção em termos militares se dá através das imagens analisadas, que representam um nós cidadãos brasileiros (mais fortemente representados pelos militares) e "eles" (refugiados venezuelanos), possibilitando a visualização de fronteiras em níveis imaginários, através de representaçóes mediadas que são frequentemente apresentadas como opostos binários, estereótipos de forma a promover um senso de segurança. Levando em conta essa indagação, o papel de acolher do Brasil pressupóe uma imagem de um anfitriáo, uma casa, uma família pronta e apta a cuidar desses "hóspedes" oriundos da crise migratória e esse atravessar da fronteira em Pacaraima diz muito sobre os venezuelanos e mais fortemente, sobre os próprios brasileiros que os recebem.

Essa história única, narrada pelos militares, contribui para um retrato positivo e comemorativo do vanguardismo brasileiro no tocante ao refúgio e do papel do Exército em "coordenar a maior missão humanitária que o Brasil já presenciou” (EM BUSCA..., 2019), legitimando a operação e a credibilidade dos "salvadores e gestores da crise" concomitante a vitimização dos refugiados, que se tornam objetos de pena. No vídeo Operação Acolhida: a mão amiga das

\footnotetext{
22 Bigo (2006) ressalta que a proteção do indivíduo ocorre através da excepcionalização de um espaço considerado sagrado, que seria o interno. Ademais, a proteção também se dá em relação à defesa contra os inimigos e a criação de fronteiras físicas que garantam a segurança interna por meio da purificação e da propagação de fronteiras.
} 
Forças Armadas (OPERAÇÃO ACOLHIDA..., 2019) as seguintes palavras são mobilizadas: "um dia a Operaçáo Acolhida encerra para estas pessoas. Seja saindo dos abrigos, conseguindo emprego, interiorizando ou até retornando para suas famílias. Em todas, o Brasil mostra mais uma vez a sua grandeza e as Forças Armadas a dedicação ao país."

Dessa forma, observa-se como determinadas políticas de assistência social/ humanitária podem ser enquadradas discursiva e esteticamente em uma lógica vulnerabilidade/risco e de uma polarização moral entre compaixão e repressão, mantendo os corpos desviantes/diferentes sob controle e propagando uma visão de piedade, humanitarismo (FASSIN, 2001, 2005).

Concomitante a essa delimitação da figura nacional brasileira - que seria a responsável por "salvar vidas", que mobiliza o Exército para uma missão ágil, coordenada, altiva - estabelece-se uma construção imaginária mas prática de quem seria o refugiado venezuelano: aquele oriundo de um país caótico, autoritário, de ideologia de "esquerda" e por conseguinte, vulnerável, frágil e inapto ao reconhecimento de regras estabelecidas, podendo causar desordem e ameaçar a integridade da democracia brasileira caso não seja acolhido de forma disciplinada e integral.

Nesse sentido, é fundamental um olhar atento para a construção de dois extremos: dos militares, com recursos de logística e pessoal em constante prontidão para um cuidado e dos carentes de auxílio, cujas trajetórias e certezas foram deixadas na Venezuela, que agora agarram-se na esperança e melhoria de vida possibilitada pelas Forças Armadas brasileiras. Apesar de aparentemente opostos, os aptos versus os passivos, os cidadãos versus os estrangeiros, os vídeos permitem uma visão além: que é circundada pela ideia de recepção, permitindo que esses "dois mundos" se encontrem "[...]com uma missão: acolher" (OPERAÇÃO ACOLHIDA..., 2019).

Dessa forma, embora o artigo enfoque no relacionamento entre duas identidades mobilizadas como distintas, para que a Operação Acolhida funcione de forma sincronizada com os interesses políticos nacionais, a mesma atua combinando política e identidade em um processo de ajuste narrativo, constitutivo e não causal.

Em outras palavras, a performance das identidades não existe como relatos objetivos sobre o que as pessoas e lugares "realmente são" e sim como sujeitos e objetos continuamente reformulados, negociados e reformulados (HANSEN, 2006) e nesse entrelaçar de histórias, as práticas visuais, estéticas dos produtos divulgados pela Operação Acolhida atuam como estratégias de representação, veiculação, estabilização da precária e disputada identidade brasileira. 
Assim sendo, as identidades aqui mobilizadas referem-se a identidades construídas através dos discursos, as quais a política torna-se dependente delas, ou seja, a identidade é entendida como política, relacional, sendo mobilizada através de discursos que constituem um Eu nacional versus um Outro estrangeiro. Nesse sentido, aquele que atravessa a fronteira e ousa adentrar o espaço nacional, além de sem agência política e lido como vítima, é diferente e, portanto, ameaçador na sua alteridade.

Seguindo essa visão, o Estado soberano moderno constitui sua identidade social demarcando simultaneamente o que é interno e externo (diferença); e envolve uma "evangelizaçáo do medo" ao construir a identidade interna/doméstica como hierárquica, pacífica e ordeira, diferente do mundo externo como lócus de anarquia, guerra e violência (CAMPBELL, 1992).

Em outras palavras, a identidade seria uma condição constitutiva dos seres sociais (individuais e coletivos) e construída a partir da diferença. Tendo em vista que todo significado pode ser constituído através da diferença, então não pode haver declaração sobre a natureza de uma dada identidade que é totalmente livre de suposiçóes sobre o outro, sendo, portanto, movimentos entrelaçados e concomitantes (CAMPBELL, 1992). Embora diversas organizaçóes da sociedade civil, pesquisadores questionem o viés humanitário da Operação, através dessa divulgação quase que mensal de imagens, vídeos, o Exército alcança legitimidade, credibilidade na transparência de suas açôes e mais, conclama a audiência a acompanhar e observar de perto a necessidade e urgência dessas práticas.

A partir de palavras-chave e imagens utilizadas pelo material da Operação, observa-se uma tentativa de exaltar o novo papel das Forças Armadas, que para além de instrumentos de guerra, configuram-se como ferramentas humanitárias utilizadas para o recrudescimento do status do Estado, como modo de promoção política no cenário global (ENETERIO; DA PAIXÃO ENETERIO; DA SILVA, 2019).

Essas imagens, vídeos e discursos amplamente divulgados pelo Exército que também se encontram na grande mídia convidam os espectadores a vivenciar o que está acontecendo na regiáo norte do Brasil através da perspectiva das autoridades governamentais e dos militares. Assim sendo, a narrativa de representação da Operação Acolhida acaba concretizando as ontologias existentes no processo desigual do atravessar das fronteiras, conferindo papeis, valores e significados hierárquicos à determinadas vidas humanas, ou seja, "ao realizar o espetáculo do 'campo de batalha humanitário', os espectadores são convidados a imaginar a humanidade de si próprios e dos outros" (MUSARÒ, 2016, p.15, tradução nossa). 
Essa política discursiva perfomada através de imagens e vídeos ajuda a reforçar a construção do imaginário de crise humanitária, trazendo a noção de urgência e reforçando uma demanda afetiva e efetiva (DEBRIX; WEBER, 2003).

Em outras palavras, a escolha de análise das divulgaçóes audiovisuais da Operação Acolhida permite mostrar como a mobilização da identidade brasileira ocorre via política material - com tropas no terreno realizando triagem e acolhimento - e visual resgatando termos de hospitalidade e hostilidade, governança humanitária em termos militarizados, unindo polos como dentro e fora que, à primeira vista parecem ser diametralmente opostos, mas que fazem parte de processos relacionais.

Nesse sentido, há uma logística do governo e do Exército aqui como seu braço militar, que pretende naturalizar narrativas nacionalistas, que constituem identidades e divisóes dentre os brasileiros militares e os refugiados venezuelanos, os hospitaleiros, aptos a auxiliarem e os receptores de intervenção.

Ao levar em conta que Brasil precisa de contextos de representação no tocante a sua política para performar sua identidade, a Operação aparece como oportunidade ímpar para que as Forças Armadas exercitem e demonstrem suas capacidades, fortalecendo uma parte da identidade brasileira, sendo uma tentativa de estabilização de um determinado entendimento político da realidade e da gestão de "crises".

Fassin e Pandolfi (2010) salientam como, a nível internacional e também nacional, tornou-se corrente a instauração de estados de emergência, de exceção, nos quais um governo militar e organizaçóes humanitárias tornam-se os modelos de resposta às situaçóes desordenadas.

Os autores, através de inúmeras contribuições de especialistas da área e que estiveram "no campo"—que possuem exemplos concretos, extraídos da pesquisa pessoal - demonstram o uso do humanitarismo como justificativa ética para um modelo de poder que é tudo menos benigno, sendo uma "ditadura benevolente: 'mesmo vestido com o manto da moralidade humanitária, a intervenção é sempre uma ação militar, em outras palavras, a guerra" (FASSIN; PANDOLFI, 2010, p.22, tradução minha).

Portanto, questionar o humanitarismo desempenhado pelos militares na Operação Acolhida torna-se fundamental para a problematização da naturalização de discursos e práticas:

Em larga medida, a construção da questão migratória como 'problema' parte do pressuposto necessário de uma 'crise' da capacidade de controle por parte dos agentes soberanos (tanto nacionais, quanto supranacionais) 
em regular, definir e delimitar quem entra, quem sai e quem fica nos seus territórios e sob quais condiçóes (AGUIAR, 2019, p.31).

Em suma, as fronteiras aqui problematizadas entre brasileiros e venezuelanos, acolhedores e acolhidos podem ser resumidas como espaços onde a política ocorre, sejam eles simbólicos, materiais, capazes de selecionar, hierarquizar, reorientar, redesenhar, resistir no processo do encontro da diferença com a identidade (GOMES, 2014).

Essas variadas práticas discursivas, que operacionalizam um "regime de verdade" particular sobre o papel do Exército e sobre o que seria o Brasil, silenciam os mecanismos de diferenciação e supressão no domínio interno do Estado que permitem a produção dessa identidade (GOMES, 2014).

Nesse sentido, solidificando a compreensão de um Brasil pacífico, acolhedor e eficiente, a Operação Acolhida utiliza-se do histórico humanitário do Exército para reforçar a tamanha eficiência e experiência da instituição:

A exemplo da atuação dos militares brasileiros no terremoto que arrasou o Haiti, tem-se testemunhado o brilhantismo, o profissionalismo e o zelo com que o exército brasileiro vem atuando nas mais diversas frentes missionárias (tanto de natureza voluntária quanto militar) pelo mundo afora, passando a ser importante instrumento para pronto atendimento em missóes e como parceiro estratégico da Organização das Naçôes Unidas (ONU), garantindo maior relevância ao Brasil no cenário internacional. (CRUZ JÚNIOR, 2019, p.431).

Assim sendo, buscou-se pensar no lançamento da operação como um momento transformador nas estratégias de comunicação do Exército brasileiro, aliando questôes logísticas com pautas políticas de veiculação da identidade mediadora, benevolente do Brasil. No entanto, foi ressaltada a ambiguidade existente nesse processo, que faz oscilar tratamento da temática migratória e os imaginários populares sobre a "identidade brasileira”. A política discursiva observada, portanto, atrela discursos de segurança que são pautados por uma dinâmica política dupla: possuem autoridade para empreender açóes decisivas e excepcionais, ao mesmo tempo em que reforçam a responsabilidade particular deles mesmos em gerir "a crise" (HANSEN, 2006). 


\section{Considerações finais}

O início da percepção brasileira sobre o fluxo migratório venezuelano ocorreu em um viés securitário, delimitando estratégias para conter essa "crise" e ressaltando o fardo do humanitarismo brasileiro de acolher esses indivíduos, realizando uma diferenciação do "Nós, cidadãos brasileiros" desses outros venezuelanos. Nesse sentido, a migração era vista "[...] as being one of the main factors weakening national tradition and societal homogeneity. It is reified as an internal and external danger for the survival of the national community or western civilization" (HUYSMANS, 2006, p.759).

Levando em conta o imaginário de emergência que a mídia e os políticos estavam mobilizando, nessa lógica securitária, de ameaça, a Operação Acolhida aparece (re)produzindo esses ideais de gestão assertiva do "problema" existente, trazendo soluçóes que a primeira vista parecem ser técnicas e ágeis para a questão.

No entanto, no momento em que os militares assumem um posicionamento liderante na operação e passam a divulgar fotografias e vídeos, percebe-se uma veemente divulgação e merchandising da instituição em estabilizar e representar uma certa "identidade brasileira", nos moldes de expertise, humanitarismo, vanguardismo no tocante ao refúgio, tradição de acolhimento, multiculturalismo, defesa dos direitos humanos.

Observa-se portanto, uma ideia de polarização presente na sociedade roraimense, colocando de um lado espectadores sensibilizados pela situação precária dos venezuelanos que chegam ao Brasil, enquanto outros defendem o fechamento da fronteira, a deportação, a restrição e cotas para o acesso aos serviços básicos. Dessa forma, o fluxo migratório venezuelano "[...] oportuniza ampliar o conhecimento sobre a própria sociedade brasileira” (SARMENTO; RODRIGUES, 2018, p.246).

Partindo da consideração da política discursivo-visual nos produtos divulgados pela Operação Acolhida, evidencia-se como as imagens e palavras-chave mobilizadas destacam exclusivamente a eficácia dos esforços dos militares em ajudar as vítimas sofredoras. Em outras palavras, em uma chave de salvadores e corpos acolhidos, as imagens representam um movimento de tentativa de legitimação da intervenção militar aos olhos do público, a fim de conquistá-lo e sensibilizá-lo através da ampla utilização de rostos de crianças que nutrindo relaçốes de afetividade para com os militares, tornam-se sinônimos da identidade mediadora, conciliadora que o Brasil busca consolidar (DEBRIX; WEBER, 
2003). Essa mediação ${ }^{23}$ foi aqui compreendida como um instrumento de significado, contribuindo para o arranjo de crenças, normas, instituiçóes e identidades na sociedade (DEBRIX; WEBER, 2003).

Diante da alteridade e adversidade, os militares constroem-se articulados com proposições políticas como "estabilizadores e pacificadores" e um dos principais interesses desse artigo foi investigar as dinâmicas materiais e mobilizaçóes discursivas que tornam possível esse tipo de atuação dos mesmos na Operação Acolhida: problematizando como o humanitarismo da nação é performatizado através da militarização de espaços e corpos, de como amparo, benevolência estão atreladas à delimitação da alteridade, e como as práticas militares e políticas ocorrem concomitantemente nessas fronteiras físicas e subjetivas entre Brasil e Venezuela. Dessa forma, o artigo buscou problematizar de que forma a "crise" foi lida e "gerenciada" pelo governo brasileiro e quais foram os papeis e interesses político-midiáticos em utilizar os exatos termos de "crises humanitárias" (ZIZEK, 2008). Ademais, buscou-se pensar como, nos discursos e imagens no tocante ao controle da mobilidade venezuelana e na governança humanitária da "crise", a administração brasileira - vulgo atuação do Exército na Operação Acolhida- coloca em ação as verdades que estava construindo sobre os venezuelanos e sobre sua própria "identidade".

Diante de um contexto internacional cada vez mais marcado pela reafirmação de muros, fronteiras e nacionalismos, pelo recrudescimento de políticas e práticas de diferenciação, pensar no papel de políticas de identidade e de demarcação do cidadão nacional frente ao refugiado torna-se um relevante instrumento de resistência e tentativa de ruptura com determinadas verdades que estão a todo tempo sendo firmadas e, por conseguinte, contestadas. Torna-se cada vez mais fundamentais os debates que questionem como determinados discursos no tocante ao refúgio são construídos, autorizados e reproduzidos nos meios políticos, midiáticos e logísticos.

Apesar das veementes críticas dentro da literatura acerca do papel dos militares em resposta a emergências, o objetivo do artigo não se concentra nessa questão. Busca-se problematizar, aqui, o papel dos discursos veiculados na mídia

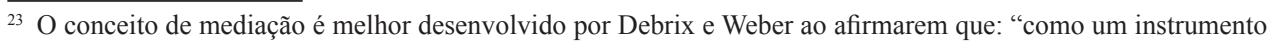
de significado, a tarefa da mediação é tipicamente alcançar relações desejáveis entre as posições de sujeito e objeto (conforme postulado pelo sistema social dentro do qual o método de mediação opera). A mediação pode estabelecer relações desejáveis por meio de conexão ou distanciamento. Como uma técnica de conexão ou distanciamento de significado, a mediação também contribui para o arranjo de crenças, normas, instituições e identidades em qualquer sociedade. A mediação mantém os significados e relações sociais que se estabelecem entre sujeitos e objetos em diferentes contextos sociais" (DEBRIX; WEBER, 2003, p.xxiii, tradução nossa).
} 
de forma ampla e por militares que funcionam (re)produzindo certas práticas de representaçáo e constituição de identidade brasileira como acolhedora, gestora da ordem, enquanto os refugiados venezuelanos, ora são colocados como ameaçadores, ora como vítimas inertes.

A sensação de urgência, provisoriedade e limbo das fronteiras são potencializadas pelos indivíduos que vivenciam todos os dias esse "vigiar" do Estado, mas ao mesmo tempo, não conseguem ser abarcados por práticas de cuidado e assistência social, colocando nos refugiados a origem de todas as suas mazelas. Ao despir o refugiado da especificidade territorial e de sua cultura, lugar e história, o refugiado torna-se um ser sem voz e sem identidade política ou as possibilidades correspondentes de agência, sendo uma questão que merece ensejar o debate ser mais aprofundada.

Sob a lente dos estudos de Segurança, a questão migratória torna-se ainda mais nebulosa, haja vista que pode ser lida por diferentes correntes com preocupaçóes desde ameaças materiais e soberanas - com enfoque no controle de fronteiras, vigilância, defesa - até mobilizaçôes discursivas e xenófobas contra essa circulação heterogênea intimidando o "construto homogêneo nacional".

Assim sendo, é fundamental o entendimento da migração através de uma chave crítica de securitização que envolva problematizaçôes pós estruturais, levando o conceito de segurança para além de ameaças físicas, objetivas, observando as representaçóes identitárias dos estados como construçóes:

Nenhum outro conceito nas relações internacionais contém o poder metafísico, nem comanda o poder disciplinar da "segurança". Em seu nome, os povos alienaram seus medos, direitos e poderes a deuses, imperadores e, mais recentemente, a estados soberanos, tudo para se proteger das vicissitudes da natureza - bem como de outros deuses, imperadores e estados soberanos. [...] E, menos frequentemente observado nas relaçóes internacionais, em seu nome bilhôes foram feitos e milhôes mortos, enquanto o conhecimento científico foi promovido e a dissidência intelectual silenciada (DER DERIAN, 1995, p. $1^{24}$, tradução nossa).

\footnotetext{
${ }^{24}$ Página referente ao pdf, já que documento não possui paginação.
} 


\section{REFERÊNCIAS}

ACNUR. Brasil torna-se o país com maior número de refugiados venezuelanos reconhecidos na América Latina. 2020. Disponível em: https://www.acnur.org/ portugues/2020/01/31/brasil-torna-se-o-pais-com-maior-numero-de-refugiadosvenezuelanos-reconhecidos-na-america-latina/. Acesso em: 24 jun. 2021.

ACNUR. Venezuela. 2018. Disponível em: https://www.acnur.org/portugues/ venezuela/. Acesso em: 01 fev. 2018.

ACNUR. Tendências Globais de Refugiados: visão geral das populaçôes de refugiados, recém-chegadas, soluçóes duradouras, requerentes de asilo e outras pessoas que preocupam o ACNUR. 2003.

AGAMBEN, G. O que é o contemporâneo?: e outros ensaios. Chapecó: Argos, 2009.

AGUIAR, C. M. Entre a crise e a crítica: migraçóes e refúgio em perspectiva global. Monçóes: Revista de Relaçóes Internacionais da UFGD, Dourados, v. 8, n. 16, p. 21-41, 2019.

ARENDT, H. On revolution. New York: Penguin Classics, 2006.

BALZACQ, T. (ed.). Securitization theory: how security problems emerge and dissolve. London: Routledge, 2010.

BIALASIEWICZ, L. et al. Performing security: The imaginative geographies of current US strategy. Political Geography, Oxford, v. 26, n. 4, p. 405-422, 2007.

BIGO, D. Protection: Security, Territory and Population. In: HUYSMANS, J.; DOBSON, A.; PROKHOVNIK, R. (ed.). The politics of protection: sites of insecurity and political agency. Hove, UK: Psychology Press, 2006. p. 96-112.

BIGO, D. When two become one: internal and external securitisations in Europe. In: KELSTRUP, M.; WILLIAMS, M. (ed.). International relations theory and the politics of European integration: power, security and community. London: Routledge, 2000. Capítulo 8.

BLEIKER, R. (ed.). Visual global politics. London: Routledge, 2018.

BLEIKER, R. The aesthetic turn in international political theory. Millennium, London, v. 30, n. 3, p. 509-533, 2001.

BOADLE, A. Onda de imigrantes da Venezuela pode gerar crise em Roraima. Exame, São Paulo, 2017. Disponível em: https:/exame.abril.com.br/brasil/onda-deimigrantes-da-venezuela-pode-gerar-crise-em-roraima/. Acesso em: 14 maio 2021. 
BOLTANSKI, L. Distant suffering: Morality, media and politics. Cambridge: Cambridge University Press, 1999.

BRASIL. Câmara dos Deputados. Medida Provisória 820/2018, de 15 de fevereiro de 2018. Diário Oficial, Brasília, 2018. Disponível em: http://www.planalto.gov.br/ ccivil_03/_ato2015-2018/2018/Mpv/mpv820.htm. Acesso em: 15 fev. 2019.

BRASIL anuncia reforço de segurança na fronteira com Venezuela. Folha de S. Paulo, São Paulo, 2018. Disponível em: https://wwwl.folha.uol.com.br/mundo/2018/02/ brasil-anuncia-reforco-de-seguranca-na-fronteira-com-venezuela.shtml. Acesso em: 23 jul. 2021.

BUZAN, B. et al. Security: a new framework for analysis. Boulder: Lynne Rienner Publishers, 1998.

CAMARGO, D. A.; HERMANY, R. Migração venezuelana e poder local em Roraima. Revista de Estudos Jurídicos UNESP, Franca, v. 22, n. 35, 2019.

CAMPBELL, D. National deconstruction: Violence, identity, and justice in Bosnia. Minneapolis: University of Minnesota Press, 1998.

CAMPBELL, D. Violent performances: identity, sovereignty, responsibility. In: LAPID, Y. et al. (ed.). The return of culture and identity in IR theory. Boulder: Rienner, 1996.

CAMPBELL, D. Writing security: United States foreign policy and the politics of identity. Minneapolis: University of Minnesota Press, 1992.

CHARLEAUX, J. P. Quais as críticas ao uso de militares na assistência a imigrantes. Nexo Jornal, São Paulo, 2018. Disponível em: https://www.nexojornal.com. br/expresso/2018/05/23/Quais-as-cr\%C3\%ADticas-ao-uso-de-militares-naassist\%C3\%AAncia-a-imigrantes. Acesso em: 28 jul. 2020.

CHOULIARAKI, L. The spectatorship of suffering. Newcastle upon Tyne: Sage, 2006.

CIRTAUTAS, K. C. The Refugee: A Psychological Study. Ponca City: Meador Publishing Company, 1957.

COMANDANTE do Exército visita Operação Acolhida. [S. l.: s. n.], 2019. 1 vídeo (2 min). Publicado pelo canal Exército Brasileiro. Disponível em https://www. youtube.com/watch?v=9mwMe_ijj4M. Acesso em: 25 ago. 2021.

CONNOLLY, W. E. Identity, difference: democratic negotiations of political paradox. Minneapolis: University of Minnesota Press, 2002. 
CONARE. Relatório Refúgio em Números. 4. ed. Brasília, 2018. Disponível em: https://www.acnur.org/portugues/wp-content/uploads/2019/07/Refugio-em-nu\%CC \%81meros_versa\%CC\%83o-23-de-julho-002.pdf. Acesso em: 05 ago. 2021.

COSTA, E.; BRANDÁO, I.; OLIVEIRA, V. Fuga da fome: como a chegada de 40 mil venezuelanos transformou Boa Vista. G1, 2018a. Disponível em https://g1.globo. $\mathrm{com} / \mathrm{rr} /$ roraima/noticia/fuga-da-fome-como-a-chegada-de-40-mil-venezuelanostransformou-boa-vista.ghtml. Acesso em: 05 jul. 2021.

COSTA, E.; BRANDÃO, I.; OLIVEIRA, V. Autoridades de Roraima pedem 'socorro' para lidar com imigração e querem 'interiorização' de venezuelanos. G1, 2018b. Disponível em: https:/g1.globo.com/rr/roraima/noticia/autoridades-de-roraimapedem-socorro-para-lidar-com-imigracao-e-querem-interiorizacao-de-venezuelanos. ghtml. Acesso em: 17 jul. 2021.

CRISE NA VENEZUELA atravessa a fronteira e chega ao Brasil com o drama dos refugiados. Globoplay, 2017. Disponível em: https://globoplay.globo.com/v/6077077/. Acesso em: 12 jul. 2021.

CRISE quintuplica número de imigrantes venezuelanos no Brasil. Veja, 2017. Disponível em: https://veja.abril.com.br/mundo/crise-quintuplica-numero-imigrantesvenezuelanos-no-brasil. Acesso em: 25 ago. 2021.

CRUZ JUNIOR, S. J. A operação acolhida e a imigração venezuelana em Roraima. Pensar Acadêmico, Manhuaçú, v. 17, n. 3, p. 430-447, 2019.

DEBRIX, F.; WEBER, C. (ed.). Rituals of mediation: International politics and social meaning. Minneapolis: University of Minnesota Press, 2003.

DE HAAS, H. The myth of invasion: Irregular Migration from West Africa to the Maghreb and the European Union. 2007. Disponível em: https://www.temaasyl.se/ Documents/Forskning/Forskningsstudier/The $\% 20$ Myth\%20of\%20Invasion $\% 20$ $\% 20 \% 20$ Irregular $\% 20$ migration $\% 20$ from $\% 20$ West $\% 20$ Africa $\% 20$ to $\% 20$ the $\% 20$ Maghreb\%20and\%20the\%20European\%20Union.pdf. Acesso em: 7 jul. 2021.

DER DERIAN, J. The Value of Security: Hobbes, Marx, Nietzsche, and Baudrillard. In: LIPSCHUTZ, R. D. (ed.). On Security. New York: Columbia University Press, 1995. p.1-120.

DOS SANTOS VASCONCELOS, I. Receber, enviar e compartilhar comida: aspectos da migração venezuelana em Boa Vista, Brasil. Revista Interdisciplinar da Mobilidade Humana, Brasília, v. 26, n. 53, p. 135-151, 2018.

DOTY, R. L. Sovereignty and the nation: constructing the boundaries of national identity. In: BIERSTEKER, T. J.; WEBER, C. (ed.). State sovereignty as social construct. Cambridge: Cambridge University Press, 1996. 
ODRAMA dos venezuelanos no Brasil. Gazeta do Povo, 2018. Disponível em: https://www.gazetadopovo.com.br/opiniao/editoriais/odrama-dos-venezuelanos-nobrasil-78p840dtq0tal2szslqbvuw6r/. Acesso em: 17 jul. 2021.

DURÃES, M. G. D.; JUNIOR, J. A. de S. A crise migratória na Venezuela e a impossibilidade do fechamento da fronteira entre Brasil e Venezuela na ótica do STF. In: BAENINGER, R.; JAROCHINSKI SILVA, J. (coord.). Migraçóes venezuelanas. Campinas, SP: Nepo/Unicamp, 2018. v. 1. p. 52-59.

EM BUSCA de oportunidade. [S. 1.: s. n.], 2019. 1 vídeo (10 min). Publicado pelo canal Operação Acolhida. Disponível em: https://www.youtube.com/watch?v=MM0FI67EQs. Acesso em: 25 ago. 2021.

ENETERIO, H. S.; DA PAIXÃO ENETERIO, N. G.; DA SILVA, A. M. $O$ paradigma da atuação dos militares nas questốes de migração forçada: um olhar interdisciplinar entre a Política e a Psicologia. Revista Interdisciplinar da Mobilidade Humana, Brasília, v. 27, n. 55, p. 131-147, 2019.

ÊXODO venezuelano 'perturba países da América Latina', diz Temer. Veja, 2018. Disponível em: https://veja.abril.com.br/mundo/exodo-venezuelano-perturba-paisesda-america-latina-diz-temer. Acesso em: 17 de março de 2019.

FASSIN, D. Compassion and repression: the moral economy of immigration policies in France. Cultural Anthropology, Arlington, v. 20, n. 3, p. 362-387, 2005.

FASSIN, D. The biopolitics of otherness: undocumented foreigners and racial discrimination in French public debate. Anthropology Today, West Sussex, v. 17, n. $1,2001$.

FASSIN, D.; PANDOLFI, M. Contemporary states of emergency: The politics of military and humanitarian interventions. New York: Zone Books, 2010.

FGV DAPP. Perfil dos imigrantes venezuelanos que chegam ao Brasil. Sáo Paulo, 2018. Disponível em: http://dapp.fgv.br/entenda-qual-o-perfil-dos-imigrantesvenezuelanos-que-chegam-ao-brasil/. Acesso em: 02 ago. 2021.

FOUCAUlT, M. Segurança, Território, Populaçáo. São Paulo: Martins Fontes, $2008 \mathrm{a}$.

FOUCAULT, M. Vigiar e punir. 35 ed. Petrópolis: Vozes, $2008 \mathrm{~b}$.

FOUCAULT, M. A microfísica do poder. 12 ed. Rio de Janeiro: Edições Graal, 1996.

GOMES, M. S. A 'Pacificaçáo' Como Prática de 'Política Externa’de (re) Produçáo do Self Estatal: Rescrevendo o Engajamento do Brasil na Missão das Naçóes Unidas para a Estabilizaçáo no Haiti (MINUSTAH). 2014. 271f. Tese (Doutorado em 
Relações Internacionais) - Pontifícia Universidade Católica do Rio de Janeiro, Rio de Janeiro, 2014.

GREENSLADE, R. Seeking scapegoats: The coverage of asylum in the UK press. Asylum and Migration Working Paper 5, London, 2005. Disponível em: https:// www.ippr.org/files/images/media/files/publication/2011/05/wp5_scapegoats_1359. pdf. Acesso em: 8 jul. 2021.

HADDAD, E. The refugee in international society: between sovereigns. Cambridge: Cambridge University Press, 2008.

HANSEN, L. Security as practice: discourse analysis and the Bosnian war. London: Routledge, 2006.

HARKIN, C. The 2004 Tsunami: civil-military aspects of the international response. London: Tsunami Evaluation Coalition, 2005. Disponível em: https://www.alnap.org/ system/files/content/resource/files/main/coordination_civil_military.pdf. Acesso em: 03 jul 2021.

HOFMANN, C-A.; HUDSON, L. Military responses to natural disasters: last resort or inevitable trend? Humanitarian Exchange, London, n. 44, p. 29- 31, 2009. Disponível em: https://reliefweb.int/sites/reliefweb.int/files/resources/1CDD40E685 147012C12576470040943D-ODI-HPN_Oct2009.pdf. Acesso em: 16 jul. 2021.

HUYSMANS, J. The politics of insecurity: Fear, migration and asylum in the EU. London: Routledge, 2006.

INVASÃO de venezuelanos em Boa Vista causa a expansão do "portunhol". Globoplay, 2017. Disponível em: https://globoplay.globo.com/v/6304054/. Acesso em: 17 jul. 2021.

JACKSON, R. Writing the war on terrorism: Language, politics and counterterrorism. Manchester: Manchester University Press, 2005.

JOHNSON, H. L. Click to donate: Visual images, constructing victims and imagining the female refugee. Third World Quarterly, Abingdon, v. 32, n. 6, p. 1015-1037, 2011.

KANAAN, C.; TÁSSIO, M.; SIDMAR, 20Ten As açóes do Exército Brasileiro na ajuda humanitária aos imigrantes venezuelanos. In: BAENINGER, R.; JAROCHINSKI SILVA, J. (coord.). Migraçóes venezuelanas. Campinas, SP: Nepo/ Unicamp, 2018. v. 1. p.68-71.

KRISTEVA, J. Desire in language: A semiotic approach to literature and art. New York: Columbia University Press, 1980. 
LUZ, C. Entenda a crise migratória de venezuelanos para o Brasil. Guia do Estudante, São Paulo, 2017. Disponível em: https://guiadoestudante.abril.com. $\mathrm{br} / \mathrm{blog} /$ atualidades-vestibular/entenda-a-crise-migratoria-de-venezuelanos-para-obrasil/. Acesso em: 17 jul. 2021.

MACHADO, V. F. Brasil visto como "vanguardista" na proteção de refugiados: reflexões críticas acerca das práticas de deferimento, acolhimento e integração local dos venezuelanos. In: SEMINÁRIO DE RELAÇÓES INTERNACIONAIS, 4., Foz do Iguaçu, Anais [...], Belo Horizonte: Associação Brasileira de Relaçóes Internacionais, 2018. Disponível em: https://www.seminario2018.abri.org.br/ download/download?ID_DOWNLOAD=4. Acesso em: 25 ago. 2021.

MANZI, L. Migrants: the scapegoats of the economic crisis. IOM: UN Migration, San Jose, 2020. Disponível em: https://rosanjose.iom.int/site/en/blog/migrantsscapegoats-economic-crisis. Acesso em: 25 ago. 2021.

MIGRAÇÃO em massa de venezuelanos muda a realidade do lado brasileiro da fronteira. R7, 2017. Disponível em: https://recordtv.r7.com/domingo-espetacular/ videos/migracao-em-massa-de-venezuelanos-muda-a-realidade-do-lado-brasileiro-dafronteira-14092018. Acesso em: 25 ago. 2021.

MILESI, R.; COURY, P.; ROVERY, J. Migração Venezuelana ao Brasil: discurso político e xenofobia no contexto atual. AEDOS, Porto Alegre, v. 10, n. 22, p. 53-70, 2018.

MOREIRA, J. B. Política externa e refugiados no Brasil: uma análise sobre o governo Lula. Carta Internacional, Belo Horizonte, v.10, ed. esp., p.133-151, 2015.

MORI, L. Se continuar assim, até o fim do ano perdemos o controle da cidade', diz prefeita de Boa Vista, cidade que mais recebe venezuelanos. BBC, 2018. Disponível em: https://www.bbc.com/portuguese/brasil-45178748. Acesso em: 20 ago. 2021.

MUSARÒ, P. Mare nostrum: the visual politics of a military-humanitarian operation in the Mediterranean Sea. Media, Culture \& Society, London, v. 39, 2016.

NIÑO, E. A. L. Questão de segurança ou de direitos humanos?: A imigração venezuelana e as mudanças na Política Externa Brasileira / Security or human rights issue? Venezuelan immigration and changes of Brazilian Foreign Policy. Mural Internacional, Rio de Janeiro, v. 9, n. 1, p. 122-137, 2018.

NUNES, J. C. Governadora de Roraima determina controle da fronteira venezuelana. Agência Brasil, 2018. Disponível em: http://agenciabrasil.ebc.com.br/economia/ noticia/2018-08/governadora-de-roraima-determina-controle-da-fronteira-venezue lana. Acesso em: 03 jun. 2021. 
NYERS, P. Rethinking Refugees: beyond states of emergency. New York: Routledge, 2006.

OLSSON, E. For Better or For Worse?: Border Policy and Discursive Constructions of Subjectivities. 2016. 56f. Dissertação (Mestrado em Ciência dos Estudos Globais) - Faculty of Social Sciences, Lund University, Lund, 2016. Disponível em: https:// lup.lub.lu.se/luur/download?func=downloadFile\&recordOId $=8879596 \&$ fileOId $=$ 8879601. Acesso em: 25 ago. 2021.

OPERAÇÃO ACOLHIDA: a mão amiga das Forças Armadas. [S. 1.: s. n.], 2019. 1 vídeo (5 min). Publicado pelo canal Exército Brasileiro. Disponível em: https://www. youtube.com/watch?v=JhntubPS30c. Acesso em: 25 ago. 2021.

OPERAÇÃO ACOLHIDA: 4o CONTINGENTE. [S. 1.: s. n.], 2019. 1 vídeo (3 min). Publicado pelo canal Exército Brasileiro. Disponível em: https://www.youtube. com/watch?v=9JyGojlUUJI. Acesso em: 25 ago. 2021.

OPERAÇÃO ACOLHIDA: CORAL formado por crianças venezuelanas emociona com canção do Exército. [S. l.: s. n.], 2019. 1 vídeo (3 min). Publicado pelo canal Exército Brasileiro. Disponível em: https://www.youtube.com/watch?v=rwt5FTiw W4E. Acesso em: 25 ago. 2021.

OPERAÇÃO ACOLHIDA: MUDANDO vidas. [S. 1.: s. n.], 2019. 1 vídeo (3 min). Publicado pelo canal Exército Brasileiro. Disponível em: https:/www.youtube.com/ watch?v=ramVj8FE9S8. Acesso em: 25 ago. 2021.

OPERAÇÃO ACOLHIDA: REFUGIADOS da Venezuela no Brasil. [S. l.: s. n.], 2018. 1 vídeo (2 min). Publicado pelo canal Exército Brasileiro. Disponível em: https://www.youtube.com/watch?v=rTEIYZlH3To. Acesso em: 25 ago. 2021.

ORIGEM DA PALAVRA. Qual a origem da palavra acolher. 2011. Disponível em: https://origemdapalavra.com.br/palavras/acolher/. Acesso em: 25 abr. 2021.

PEDROSO, C.; JAROCHINSKI SILVA, J. Los impactos de la crisis venezolana en las relaciones con Brasil: diagnóstico y perspectivas en un contexto de câmbios. In: VARÓN, L. S.; CALDERÓN, C. H. La crisis venezolana: impactos y desafíos. Bogotá: Fundación Konrad Adenauer, 2019. p.50-85.

PEDUZZI, P. Juiz suspende entrada de venezuelanos no Brasil. Agência Brasil, 2018. Disponível em: http://agenciabrasil.ebc.com.br/justica/noticia/2018-08/juizsuspende-entrada-de-venezuelanos-no-brasil. Acesso em: 24 jun. 2021.

RIBEIRO, V. Governo prorroga por um ano Operação Acolhida a venezuelanos. Agência Brasil, 2019. Disponível em: http://agenciabrasil.ebc.com.br/direitos-huma nos/noticia/2019-01/governo-prorroga-por-um-ano-operacao-acolhida-venezuelanos. Acesso em: 07 jun. 2021. 
ROXO, S. Venezuelanos levam o caos a Roraima. O Globo, 2016. Disponível em: https://oglobo.globo.com/brasil/venezuelanos-levam-caos-roraima-20419502. Acesso em: 25 ago. 2021.

SARMENTO, G.; RODRIGUES, F. Entre a Acolhida e o rechaço: breves notas sobre a violência e os paradoxos da migração venezuelana para o Brasil. In: BAENINGER, R.; JAROCHINSKI SILVA, J. (coord.). Migraçóes venezuelanas. Campinas, SP: Nepo/Unicamp, 2018. v. 1. p.242-249.

SCHMITT, C. The concept of the political: Expanded edition. Chicago: University of Chicago Press, 2008.

SHAPIRO, M. J. Studies in trans-disciplinary method: After the aesthetic turn. London: Routledge, 2013.

SILVERSTONE, R. The sociology of mediation and communication. In: CALHOUN, C.; ROJEK, C.; TURNER, B. S. (ed.). The Sage handbook of sociology. Newcastle: Sage, 2004. p.250-370.

TAXA de inflaçâo na Venezuela foi de 130 060\% em 2018. Diário de Notícias, Lisboa, 2019. Disponível em: https://www.dn.pt/dinheiro/interior/venezuela-taxa-deinflacao-de-130-060-em-2018-10953595.html. Acesso em: 30 maio 2021.

TEMER diz que Brasil acolhe venezuelanos, e mundo tem o dever de proteger refugiados. UOL, 2018.Disponível em: https://noticias.uol.com.br/internacional/ ultimas-noticias/2018/09/25/temer-discurso-onu-venezuela.htm. Acesso em: 25 ago. 2021.

TOLEDO, M.; KNAPP, E. Invasão de venezuelanos fugindo de crise no país gera caos em Roraima. Folha de S. Paulo, São Paulo, 2016. Disponível em: https://www1. folha.uol.com.br/mundo/2016/11/1833815-invasao-de-venezuelanos-fugindo-decrise-no-pais-gera-caos-em-roraima.shtml. Acesso em: 23 jun. 2021.

VAUGHAN-WILlIAMS, N. Border Politics: The Limits of Sovereign Power. Edinburgh: Edinburgh University Press, 2009.

WÆVER, O. Securitization and Desecuritization. In: LIPSCHUTZ, R. D. (ed.). On Security. New York: Columbia University Press, 1995. p.15-167.

WILLIAMS, J. The ethics of territorial borders: drawing lines in the shifting sand. Berlin: Springer, 2006.

ŽIŽEK, S. Violence: Six sideways reflections. London: Picador, 2008.

Recebido em: 10 de julho de 2020

Aprovado em: 08 de dezembro de 2020 